\section{India opens up its nuclear reactors to foreign inspection}

[NEW DELHI] India is to throw open two of its nuclear reactors for inspection by international experts. It has also invited International Atomic Energy Agency (IAEA) specialists to review the design of its new 500-MW reactors - the first invitation in its 40-year nuclear history.

Hans Blix, director general of the IAEA, last week applauded the Indian proposal for international peer review. He said: "It may be an effective method of discovering shortcomings." Blix was in Delhi to inaugurate a world conference on the role of nuclear energy for sustainable development to mark the fiftieth year of India's independence and the fortieth anniversary of the IAEA.

The moves are seen as a response to criticism (see Nature 381, 723; 1996) that the country operates vintage reactors of unsafe design. India also wants to dispel the notion it is living in nuclear isolation having refused to sign the Comprehensive Test Ban Treaty.

"Opening up our power plants or subjecting their design to peer review has nothing to do with the IAEA convention on safety of nuclear plants, which India has signed but not ratified," says Yelleswarapu Sivaram Prasad, managing director of the state-owned Nuclear Power Corporation (NPC), which designs, builds and operates the country's nuclear power stations.

"What we are doing is voluntary and is a confidence-building measure," says Prasad, "We want the world nuclear community to find out for themselves that our designs are good and safe."

India has eight 220-MW pressurized heavy water reactors (PHWR) and two USbuilt 160-MW light-water reactors in operation. Prasad says the Kakrapar nuclear power station in Gujarat, consisting of two PHWR units, will be opened up in November 1997 for visits by members of the Tokyo-based World Association of Nuclear Operators.

"They are free to inspect the control and safety features installed in the power station and watch all the activities going on," Prasad says. "We are not afraid of criticism."

The 220-MW units are based on a standardized Canadian design, but the IAEA team will also review the 500-MW scaled-up version, the first reactor fully designed by NPC. "Should any changes be suggested, we will incorporate them," Prasad says. The first two reactors in the 500-MW series are to be built at Tarapur near Bombay (now Mumbai) with construction to start next year.

Officials hope the open policy may also help India boost its nuclear power production through private-sector participation, both Indian and foreign.

K.S.Jayaraman

\title{
Uncertain aims delay start of Internet research effort
}

[WASHINGTON] The Next Generation Internet (NGI), a \$100-million-a-year research initiative intended to ensure the future leadership of the United States in Internet technology, is getting off to a slow start because of lingering doubts in Congress about its purpose and the geographical distribution of funds to support it.

The programme was announced by President Bill Clinton during his successful reelection campaign last October. It is meant to put those US research agencies that laid the groundwork for what is now the Internet at the forefront of efforts to develop future universal networks of far higher capability.

Almost everyone in the Congress shares that objective. But after initial confusion about the nature of the programme, various congressional committees have been reluctant to provide money for it. As a result, NGI may stagger into 1998 with only half the $\$ 105$ million requested by Clinton for its first year.

NGI has been designed by the administration to carry out the research needed to develop the Internet of the future. It is distinct from Internet 2, a project by a hundred research universities in the United States to establish a fast network for their own exclusive use to bypass the clogged arteries of the existing Internet.

The popularity of the Internet in the United States - bolstered by unlimited domestic access via free local telephone lines - has made it slower there than in many other countries.

The administration has divided NGI into three parts. The first, to be led by the Defence Advanced Research Projects Agency (DARPA), is intended to develop technologies and protocols for a much faster Internet.

The second, according to the project plan, will "weave the next generation network fabric" by developing a test bed of 100 linked sites for the new network. The administration wanted the Department of Energy (DOE) to lead this, but is now coming round to Congress's view that the National Science Foundation (NSF) should lead it.

The third element, which will involve several government agencies, would develop

\begin{tabular}{llll}
\hline \multicolumn{3}{l}{$\begin{array}{l}\text { US funding proposals for the Next Generation } \\
\text { Internet research initiative }\end{array}$} \\
\hline Agency & $\begin{array}{l}\text { Clinton } \\
\text { request }\end{array}$ & $\begin{array}{c}\text { House } \\
\text { approp. }\end{array}$ & $\begin{array}{c}\text { Senate } \\
\text { approp. }\end{array}$ \\
\hdashline DARPA & $\$ 40 \mathrm{~m}$ & $\$ 40 \mathrm{~m}$ & $\$ 10 \mathrm{~m}$ \\
\hdashline DOE & $\$ 35 \mathrm{~m}$ & 0 & 0 \\
\hdashline NSF & $\$ 10 \mathrm{~m}$ & $\$ 23 \mathrm{~m}$ & $\$ 10 \mathrm{~m}$
\end{tabular}

"revolutionary applications" for the new network. But by the time details of this plan were finalized in July, congressional appropriations panels had shunned the initiative.

Congressional staff of both parties lay the blame for this at the door of the Office of Science and Technology Policy (OSTP), the White House science office responsible for coordinating the initiative across the federal government. They say that OSTP was too slow to formulate details of the proposal after Clinton announced it.

"The train left the station before we had any realistic idea of where it was going," says James Sensenbrenner (Republican, Wisconsin), who chairs the Science committee in the House of Representatives. The committee failed to approve any money for the programme when it recommended funding levels for research programmes under its jurisdiction back in March.

Complaints then surfaced from powerful senators for rural states, notably Ted Stevens (Republican, Alaska), who chairs the appropriations committee, and Conrad Burns (Republican, Montana), who feared that the initiative would discriminate against remote locations. The NSF has since offered $\$ 200,000$ to help some rural states gain access to high-speed links. But at a hearing of the House Science committee last week, Joe Thompson of Mississippi State University said that this would cover "less than 10 per cent" of the extra costs these states face.

When appropriations subcommittees considered NGI funding in June and July, the patchy outcome reflected both geographical and organizational concerns (see table). This month, the House and the Senate will compromise on the funding levels for this and other programmes at each agency. Sensenbrenner says NGI is likely to end up with " 50 to 60 per cent" of the $\$ 105$ million the administration wanted for it in 1998.

Since the plan was published in July, the NGI initiative has won the support of many key players in the Congress, and is likely to be fully funded in 1999. As the purpose of the initiative becomes clearer, and the administration moves to accommodate the concern of states that fear being left behind, support should solidify.

But the delay in starting the initiative could dent its relevance to a field of technology which moves more quickly than the funding system can handle. As Henry Kelly, acting associate director of OSTP, told the hearing: “The danger here is that we'll have a slow start, which is an unfortunate situation when you're dealing with a technology that moves like lightning." 